\title{
Beyond Traditional Social Work with Elderly: Reflections from Ukraine in Times of Social Distancing
}

\author{
Tetyana Semigina ${ }^{1}$, Olena Karagodina ${ }^{1}$, Oksana Pozhydaieva ${ }^{1}$ \\ ${ }^{1}$ Academy of Labour, Social Relations and Tourism \\ 3-A Kiltseva Doroha, Kyiv, 03187, Ukraine
}

DOI: $10.22178 /$ pos.70-6

JEL Classification: 139

The global COVID-19 pandemic envokes numerous challenges in many areas of societies, including social services. The idea of 'social distancing' contradicts the whole idea of social work and inevitably causes deepening social exclusion. This study is aimed to analyse peculiarities of Ukrainian social workers' activities under severe quarantine restrictions or lockdown. Special attention is paid to local social services for the elderly as a group recognised as most vulnerable to COVID-19.

Received 28.04.2021

Accepted 28.05.2021

Published online 31.05.2021

A survey of representatives of territorial centres of social services in Ukraine, conducted in August 2020, revealed some problems caused by restrictive quarantine measures and positive changes in the centres. The study highlights some surprising

Corresponding Author:

Semigina.tv@socosvita.kiev.ua

(c) 2021 The Authors. This article is licensed under a Creative Commons Attribution 4.0 License @ (1) contradictions in the impact of the pandemic on social work practice with the elderly. Social services providers in local communities (territorial centres of social services, social services centres for families, children, youth, etc.) received almost no additional support during the quarantine. Yet, they consider introducing new, distant forms of communication, adjusting the work schedule, etc., as positive changes in service provision.

The study determines that the response to the challenges of a problematic situation depends on local characteristics and mostly on human resources - work organisation and professional adaptability. An important role belongs to the ability of social workers to act in emergencies, the availability of standard procedures, protocols, and resources for use in such situations, understanding the need to adhere to values of social solidarity. The specific applications from the study results are drawn for Ukrainian social work.

Keywords: COVID-19; elderly; lockdown; pandemic; social services.

\section{INTRODUCTION}

The global COVID-19 pandemic threw down emergency alternations in many areas of societies $[1,14,20]$. This pandemic becomes a disastrous crisis (real 'Corona crisis') for the Ukrainian state, market, and population.

In Ukraine, starting in March 2020, the vast majority of jobs at face-to-face communication sites, schools and universities were closed, public transport was restricted, and public meetings were postponed or cancelled. Visits to medical and social facilities were also restricted. In addition to these measures, considerable attention has been paid to enhancing responsibility for one's health and safe behaviour towards others, including hand hygiene, cough etiquette, physical (called 'social') distance, and self-isolation when necessary, to stop or slow down the spread of the virus. And although strict nationwide lockdown to enable social distancing norms eventually turned into a so-called adaptive form, the restrictions for social services institutions continued.

The burden of the restrictive measures is shared disproportionally: the interests of small and medium businesses are sacrificed and neglected, and the needs of the working people in general, not saying about the disadvantaged and deprived strata [24]. The deterioration of the economic situation has forced more and more people to seek social support and express dissatisfaction with social services' unavailability. At the same time, social workers faced a new reality of performing professional functions, as they had no experience working in situations of quarantine restrictions and emergency challenges [12]. Cri- 
sis counselling and psychological support, the socalled hotlines, were the first to be successfully established in the format of remote delivery of services to the population, yet that arisen the issue of the digital divide. The practice of social work must respond sensitively to society's new demands and those social changes that determine the situation of vulnerable groups.

This study aims to analyse Ukrainian social workers' peculiarities under severe quarantine restrictions or lockdown. Special attention is paid to local social services for the elderly as a group recognised as most vulnerable to COVID-19.

\section{Literature review}

Some studies (N. Kipgen [14]; S. Rahman [16]; Y. Zhang, B. Jiang, J. Yuan, Y. Tao [25]] conducted since the beginning of the COVID-19 pandemic demonstrate that the response to the pandemic at the global and national levels has had a significant impact on lifestyles and has raised a lot of question about how we support the most vulnerable and how it is possible to provide the proper care under the restriction measures.

According to T. Harrikari [9], in many countries, coercive efforts have been taken to enforce emergency legislation, and individual social responsibility has been strengthened. Researchers E. Keddell, L. Beddoe [13] note, unusual societal rules required rapid adaptation, which in part was considered difficult, and at the same time, the testing of new norms of behaviour for public institutions, public institutions, and individuals. All of this falls to the typical public reactions to new epidemics described by P. Strong [21, p. 249] as "as 'fear, panic, stigma, moralising and calls to or for action ... Societies are caught up in an extraordinary emotional maelstrom which seems, at least for a time, to be beyond one's immediate control".

According to researchers from different countries (C. Czymara, A. Langenkamp, T. Cano [4]; M. Dauti, E. Dhëmbo, E. Bejko, M. Allmuça [5]; G. Goggin, K. Ellis [7], UNICEF [23]), the current pandemic already has direct and indirect consequences. The direct social consequences include loss of work and income in some families, and thus deterioration of socio-economic status; high risks of infection in various inpatient social institutions, permanent institutions, and related actions to relocate some clients of such institutions, including children, to families or alternative forms of maintenance; restricting the physical accessibility of many social services, etc. Indirect consequences include 1) an increase in domestic violence, particularly against children; 2 ) increasing the vulnerability of the elderly and marginalised social groups; 3) return of circular labour migrants; 4) increased anxiety and depression; 5) increasing social instability and "cognitive wars" (dissemination of false information that distorts reality, increases despair and destroys individual responsibility). S. Rahman points out the issue of deepening social exclusion, as social distancing exposes enduring inequities.

Researchers T. Semigina, T. Skliar [19] note, that quarantine measures have led to the emergence of new norms of behaviour, which guided both the state and many citizens, particularly strengthening control and neglect of public opinion. These implications draw attention to social work principles as a collective responsibility, respect for human dignity and human rights, empowerment of marginalised (A. Pentini, W. Lorenz [15]; R. Truell [22]), and social workers' professional qualifications and the problems they face in society the new working conditions.

An analysis of international experience (T. Harrikari [9]; UNICEF [23]) shows a greater readiness to act in a pandemic of social work institutions in those countries where an appropriate emergency response system is in place. Social workers are trained to act in such circumstances; emergency care, including medical and primary psychological care, was provided, and community resources for mutual assistance.

International organisations stress that despite rapid response measures, including 'social distancing', the effective recovery from the socioeconomic crisis caused by the coronavirus could be achieved only by expanding the universal social protection system (International Labour Organization [10]; International Federation of Social Workers [11]; UNICEF [23]). To do this, it is necessary to expand the coverage of existing programs, simplify the criteria for access to assistance, and introduce new programs. This, in turn, requires the mobilisation of social resources and political will.

So, the response to the epidemic should be multilevel and comprehensive, based on the ideas of collective solidarity and readiness to tackle the emergency. 


\section{METHODOLOGY}

The study was conducted according to the methodology of "rapid appraisal", which involves achieving a preliminary understanding of the situation, identifying the most acute problems and available solutions [2]. It includes 1) survey of crucial informants; 2) desk review of available official information and research reports.

The survey of "key informants" was chosen as a technological solution to the tasks of "rapid assessment". In August 2020, a mini-survey was conducted in Kyiv and Dnipro. It was arranged with representatives of the administrative staff of the territorial social services centres. The purpose of this appraisal was to identify the problems caused by the COVID-19 epidemic and quarantine restrictions in the activities of specialists of centres that provide social services to the elderly. Invitations to participate in the survey were sent to ten centres in Kyiv and seven centres in Dnipro. Consent to participate in the survey was obtained from four centres in Kyiv and seven centres in Dnipro. Thus, a total of 11 respondents took part in the survey.

The main thematic areas of the survey were: (a) the problems faced by the staff of the territorial centres during the epidemic, (b) the ways to overcome these problems, and (c) the resources used to solve the problem situations or received by the institutions in connection with the epidemic. The texts of the answers were analysed, which contained stylistic and semantic components. The answers were evaluated on the indicators of expansiveness - conciseness, depth - superficiality, analytical - formal; semantic analysis was to comprehend, compare, and summarise the respondents' facts.

The retrospective desk review was aimed to enrich the picture and place the key informants' visions in the broader context of the national response to the pandemic in Ukraine. The techniques of thematic analysis were applied.

\section{RESULTS AND DISCUSSION}

The beginning of the lockdown period in Ukraine occurred when implementing new legislation on social services. At that moment, some regulations defining specific issues of social services centres activities, the order of interaction between institutions, specific procedures necessary for the implementation of the reform, and in particular, the provisions of the new version of the Law on Social Services were adopted with significant delays, often contain contradictions, or have not yet been developed and approved [3]. Thus, many procedures for receiving social services, benefits, payments were not transparent and understandable.

At the same time, since 2014, the decentralisation reform has been underway in Ukraine. Its primary purpose is to transfer power, authority, and resources to local governments to ensure the population's safety and well-being. Up to now, the clear distinctions between the state and local communities' responsibilities regarding social services provision are absent [17]. Public services are financed through the local budget, but they should act according to the national regulations in many cases.

In April 2020, people over the age of 60 were forced to isolate themselves and not leave home unnecessarily; the number of responsibilities of social workers increased, and they often had to spend more time with their clients. So, according to respondents, the intensity and frequency of home care assistance increased during quarantine, as daily activities, such as going to the store during quarantine, became risky for some older people.

Another additional burden was the introduction by the Ministry of Social Policy of Ukraine to the food kits for the elderly. The delivery of this inkind support was also the responsibility of social workers and their main job.

Respondents also reported an increase in the workload of social workers, mainly because workers with young children were granted leave for the period of quarantine restrictions.

Social services providers in local communities (territorial centres of social services, centres of social services for families, children and youth, etc.) received almost no additional support during the quarantine and other employees of these institutions. For example, most territorial centres did not receive any additional funds to cope with the new needs of the older people that arose during the quarantine because these funds are not in local budgets.

Describing the challenges facing social institutions at the beginning of implementing strict quarantine measures in Ukraine, respondents mentioned the need to purchase disinfectants and disposable masks. The problem was the lack 
of funds to purchase many personal protective types of equipment against the background of their significantly rising cost. They tried to solve the problem by allocating additional funds to purchase personal care products for employees.

Most respondents pointed to obstacles related to the temporary suspension and restriction of the regular operation of public transport during the lockdown. As a result, there were difficulties with the arrival of employees to work, delivery of food, and necessities to persons who use the centre's social services. In the future, this problem was solved by issuing passes for employees to travel on public transport, official transport, and private transport of local volunteers. Employees living at a considerable distance from the centre were transferred to remote work. In addition, a few respondents noted that their work schedules had changed significantly, which made it possible to optimise the institution's activities and allocate human resources more rationally.

There was a lack of national guidelines on how to provide social services in a state of emergency. Most of the respondents noted that only the orders of the local authorities, to some extent, allowed to work. However, guided by the requirements to limit social contacts, the centres were obliged to stop serving citizens in the daycare centre. As a result, the employees of these departments got rid of the routine professional workload, and they were issued a temporary downtime. In turn, the additional burden fell on those who remained to work. In order not to lose their clients - recipients of social services, the shopping centre employees tried to identify the additional needs of their clients by phone, which arose against the background of the epidemic and led to the aggravation of their life problems.

The most significant burden on employees was the need to deliver products to the elderly who do not have the support of relatives. But this challenge also had a reverse - positive - aspect. According to one respondent, "the decision to deliver food kits home to each customer made it possible to keep the elderly at home, which reduced the risk of spreading the disease. In addition, it improved not only the material condition of each of them but also the mood... ». Only in two districts of the city did the respondents state that they did not receive "special instructions..., everything was in working order". Accordingly, they did not feel adequate support from management due to constructive instructions.
At the end of May 2020, the Cabinet of Ministers issued a resolution with a clear list of providers of public social services who had to ensure a $100 \%$ salary increase. However, apart from the apparent delay, the biggest problem is that this additional payment must be made at the expense and within the limits of local budget expenditures according to the law. That required redistribution of funds from the existing local budgets to social services was impossible in many local communities.

Regarding the positive changes in the centre's organisation during the quarantine, almost all respondents noted increased team cohesion and mutual support. Restrictions on face-to-face meetings and staff meetings encouraged them to master the means of remote communication, mainly to communicate in group chats to respond quickly to unusual situations and make urgent decisions. New forms of organisation of activities for employees contributed to developing such professional qualities as mobility, flexibility, and rapid adaptation to change. Respondents indicated an awareness of greater responsibility for their own lives and the lives of those around them. At the same time, during the quarantine restrictions, some of them felt a more apparent need, the importance of their professional activities.

During the first wave of the epidemic, significant support of the centre's staff was a monetary incentive (surcharge for work in quarantine) and assistance from the local community, volunteers in providing temporary use of vehicles [12].

It is worth mentioning that during the first wave of the coronavirus epidemic in Ukraine, not only social service providers were confused. According to Ukrainian experts, the national health care system and specialised rapid response structures have proven to be largely unprepared to deal with large-scale biological disasters [8, 24]. Domestic practitioners lack professional readiness for social work in disasters. Our survey shows that social institutions and social workers have to wait for additional regulations and instructions, find ways to respond to new requests and challenges caused by restrictive measures, and lack standard procedures, protocols, and resources for emergencies.

The challenges Ukrainian social service institutions experiencing during the COVID-19 lockdown $[3,12,19]$ are presented in table 1 . 
The International Federation of Social Workers [11] states that social workers should advocate for social services to remain open during lockdown and quarantine, to adapt social services to the new world, and solve ethical dilemmas. We agree with A. Bobrova and N. Lomonosova [3], that it is necessary to finance from the local communities' budgets to establish favourable conditions for safe visits to social centres for those who need social adaptation, rehabilitation, daycare to provide services on an alternative basis, including E-services. The increase in the workload in providing social services, which is growing due to the pandemic and quarantine restrictions, should be accompanied by the opening of new staff units in the relevant public institutions (social centres). If local budgets do not have enough funds for this, these additional expenditures should be financed by additional sectoral subventions for these needs to local budgets.

Table 1 - Critical challenges for social service institutions operating during the lockdown

\begin{tabular}{|l|l|}
\hline \multicolumn{1}{|c|}{ Managerial aspects } & \multicolumn{1}{c|}{ Social aspects } \\
\hline * Restrictions on & * Growing clients' needs \\
access to social & * Increasing restrictions \\
institutions & * The unpreparedness of \\
* New responsibilities & social workers to act in \\
for social workers & emergencies \\
* Reducing the & * Lack of relevant skills \\
number of actually & for new formats \\
working staff & * Lack of supervision and \\
* New help formats & mutual support networks \\
* Lack of guidelines & \\
\hline
\end{tabular}

According to sociological research [6], the population of Ukraine in the times of lockdown experienced a very significant and traumatic psychological distress. Belonging to a vulnerable group was a predictor of such stress. Social workers who provide services to members of this group in emergencies may experience helplessness and secondary traumatic stress; they could be caught by 'emotional maelstrom' [21]. To avoid such reactions, workers need to understand their safe behaviour, the balance of professional and personal, and most importantly, a combination of professional support and specially organised recovery social interactions should be provided. At present, questions remain open for Ukraine: who will help social workers properly assess their condition and constantly monitor its dynamics; should professionals provide appropriate support to social workers to facilitate their recovery?

The ongoing COVID-19 pandemic has proven that although the profession of social work originated in Ukraine more than two decades ago, and there have been significant changes in its field since then [18], the strengthening of the profession will require further much more organised effort. It is also time to conduct in-depth research, in particular with the involvement of clients, to determine the impact of urgent, largescale (including catastrophic) situations on social work practices, means of counteracting "social distancing" and social exclusion caused by forced physical distance, and upholding social justice.

\section{CONCLUSIONS}

The social changes caused by the COVID-19 pandemic have inevitably affected social work practice on a global scale. At present, implementing the principles of social justice by meeting the needs of social work clients, adapting services and programs to new realities have become relevant in various countries around the world.

The study highlights some surprising contradictions in the impact of the pandemic on social work practice. A survey of representatives of territorial centers of social services in Ukraine, conducted in August 2020, revealed a number of problems caused by quarantine restrictive measures (the need to purchase hygiene products, difficulties with the arrival of employees to work, delivery products, restrictions on the provision of social services in the center, increasing the workload due to personnel changes, filling in additional documents, providing explanations to customers, etc.) and positive changes in the centers (mastering remote forms of communication, in particular, their use of communication in group chats for prompt response and decisionmaking, adjusting the work schedule of social workers and workers, receiving in-kind assistance in the form of food, hygiene products from retail chains, charitable foundations for lowincome single elderly people and people with disabilities went to the high-risk group; involvement of volunteers in providing assistance to clients and ensuring the work of employees). In the face of the challenges of an extreme situation, the development of self-analysis, professional reflection, the introduction of practices of professional interaction, the formation of professional sup- 
port networks for the frontline professionals becomes especially important.

The particular note is the provision of personal protective equipment and safety for social workers. It is not always possible to go through lengthy procedures to find additional funds for their purchase. Such funds should always be in a social institution, especially in pandemics, the approach of seasonal epidemics, or the threat of other biological hazards. Moreover, standard procedures, protocols, and resources for emergencies should be developed for social services, while social workers have to be trained to act in times of uncertainty and panic. Thus, teaching about social work responses to crises and disasters should be included in the curriculum.

\section{REFERENCES}

1. Aman, Q., \& Altass, S. (2021). Pre-and Post-COVID-19 condition, performance and future of the airline industry: Evidence from accounting data. Revista Amazonia Investiga, 10(37), 9-23. doi: 10.34069/ai/2021.37.01.1

2. Beebe, J. (1995). Basic Concepts and Techniques of Rapid Appraisal. Human Organization, 54(1), 4251.

3. Bobrova, A., \& Lomonosova, N. (2020, November 03). Koronavirus i sotsialnyi zakhyst: mizh reformoiu i kryzoiu [Coronavirus and social protection: between reform and crisis]. Retrieved from https://www.cedos.org.ua/en/articles/koronavirus-i-sotsialnyi-zakhyst-mizh-reformoiui-kryzoiu (in Ukrainian)

[Боброва, А., \& Ломоносова, Н. (2020, Листопад 03). Коронавірус і соціальний захист: між реформою і кризою. URL: https://cedos.org.ua/researches/koronavirus-i-sotsialnyi-zakhystmizh-reformoiu-i-kryzoiu].

4. Czymara, C. S., Langenkamp, A., \& Cano, T. (2020). Cause for concerns: gender inequality in experiencing the COVID-19 lockdown in Germany. European Societies, 23(sup1), S68-S81. doi: $10.1080 / 14616696.2020 .1808692$

5. Dauti, M., Dhëmbo, E., Bejko, E., \& Allmuça, M. (2020). Rethinking the transformative role of the social work profession in Albania: Some lessons learned from the response to COVID-19. International Social Work, 63(5), 640-645. doi: 10.1177/0020872820940356

6. Dembitskyi, S. S., Zlobina, O. G., Sydorov, M. V.-S., \& Mamonova, H. A. (2020). The state of psychological distress among various social groups in Ukraine during the COVID-19 pandemic. Ukrainian Society, 2, 74-92. doi: 10.15407/socium2020.02.074

7. Goggin, G., \& Ellis, K. (2020). Disability, communication, and life itself in the COVID-19 pandemic. Health Sociology Review, 29(2), 168-176. doi: 10.1080/14461242.2020.1784020

8. Gomza, I. (2020, May 18). Ukraine Rides High While COVID-19 Lays Neighbors Low But For How Long. Retrieved from https://www.ponarseurasia.org/memo/ukraine-rides-high-while-covid19-lays-neighbors

9. Harrikari, T. (Ed.). (2020). COVID-19 and social work: a collection of country reports. Retrieved from https://www.iassw-aiets.org/wp-content/uploads/2020/07/IASSW-COVID-19-and-SocialWork-Country-Reports-Final-1.pdf

10. International Labour Organization. (2020). Social protection responses to the COVID-19 pandemic in developing countries: Strengthening resilience by building universal social protection. Retrieved from https://www.social-protection.org/gimi/RessourcePDF.action?id=56542

11. International Federation of Social Workers. (2020). The Social Work Response to COVID-19-Six Months On. Retrieved from https://www.ifsw.org/wp-content/uploads/2020/07/2020-07-01SW-Response-to-COVID-19-Six-Months-On.pdf

12. Karagodina, O., Pozhidayeva, O., \& Semigina, T. (2020). Practice of social work in the conditions of quarantine restrictive measures: rapid appraisal and lessons. Social Work and Education, 7(4), $452-465$. 
13. Keddell, E., \& Beddoe, L. (2020). The tyranny of distance: The social effects and practice adaptations resulting from Covid-19 lockdown rules. Aotearoa New Zealand Social Work, 32(2). doi: 10.11157/anzswj-vol32iss2id741

14. Kipgen, N. (2020). COVID-19 pandemic and racism in the United States and India. Economic and Political Weekly, 55(6). Retrieved from https://www.epw.in/journal/2020/23/commentary/covid-19-pandemicand-racism-unitedstates-and.html

15. Pentini, A. A., \& Lorenz, W. (2020). The Corona crisis and the erosion of "the social" - giving a decisive voice to the social professions. European Journal of Social Work, 23(4), 543-553. doi: $10.1080 / 13691457.2020 .1783215$

16. Rahman, S. Y. (2020). "Social distancing" during COVID-19: the metaphors and politics of pandemic response in India. Health Sociology Review, 29(2), 131-139. doi: 10.1080/14461242.2020.1790404

17. Semigina, T. (2020). Local Self-Government Transformations in Ukraine and Reforms of Social Services: Expectations and Challenges. Path of Science, 6(1), 1001-1006. doi: 10.22178/pos.54-1

18. Semigina, T., \& Boyko, O. (2014). Social work education in the post-socialist and post-modern era: Global Social Work, 257-270. doi: 10.2307/j.ctv1fxm2q.22

19. Semigina, T., \& Skliar, T. (2020). Vidpovid sotsialnoi roboty na vyklyky pandemii COVID [The response of social work to the challenges of the COVID pandemic]. Paradigmatic view on the concept of world science, 1. doi: 10.36074/21.08.2020.v1.56 (in Ukrainian) [Семигіна, Т., \& Скляр, Т. (2020). Відповідь соціальної роботи на виклики пандемії COVID. Paradigmatic view on the concept of world science, 1. doi: 10.36074/21.08.2020.v1.56].

20. Skliar, N., Begma, V., \& Vrublevska, O. (2021). New challenges for the defense industrial enterprises of Ukraine in the conditions of the global pandemic. Revista Amazonia Investiga, 10(37), 45-55. doi: 10.34069/ai/2021.37.01.4

21. Strong, P. (1990). Epidemic psychology: a model. Sociology of Health and Illness, 12(3), 249-259. doi: 10.1111/1467-9566.ep11347150

22. Truell, R. (2020, March 26). As Social Workers Work Through the COVID 19 Crisis We Work Towards a Better World. Retrieved from https://www.ifsw.org/as-social-workers-work-through-thecovid-19-crisis-we-work-towards-a-better-world

23. UNICEF (2020). Social service workforce safety and well-being during the COVID-19 response. Retrieved from http://socialserviceworkforce.org/system/files/resource/files/Social-ServiceWorkforce-Safety-and-Wellbeing-during-COVID19-Response.pdf

24. Yakushik, V. (2020). Corona virus crisis in Ukraine. Some interim subjective assessments. Retrieved from https://blog.uiamp.org.ua/corona-virus-crisis-ukraine-some-interim-subjectiveassessmentsslava

25. Zhang, Y., Jiang, B., Yuan, J., \& Tao, Y. (2020). The impact of social distancing and epicenter lockdown on the COVID-19 epidemic in mainland China: A data-driven SEIQR model study. doi: 10.1101/2020.03.04.20031187 